\title{
Study on the Status Quo of University Students' Digital Capabilities as well as Countermeasures for Promotion
}

— Taking University Students in XiangNan University As an Example Xia Ouyang ${ }^{1, a^{*}}$, Ping Zhang ${ }^{1}$, Sha $\mathrm{Wu}^{1}$ and Changhai Tian ${ }^{1}$

${ }^{1}$ School of Economics and Management in Xiang Nan University, ChenZhou of Hunan, China a23225574@qq.com

Keywords: Digital ability; Digital study; Digital survival; University student;

\begin{abstract}
With the quick development of information technology, digital ability has become a necessary and basic ability for contemporary University students. In this paper, it first elaborates the structure and elements of digital ability, and then it further establishes corresponding evaluation index system from the consciousness level, knowledge level, technology level, behavior level, management level and evaluation level. Meanwhile, questionnaire method has been adopted to investigate the digital ability of University students in Xiang Nan University. In the end, it proposes some countermeasures to improve the deficiencies so as to promote University students' digital ability.
\end{abstract}

\section{Introduction}

With constant development and maturity of Internet technology as well as information technology, digitization has been infiltrated into various aspects of our life and production, forming a digital world with multi-media equipment as carrier by depending on the virtual space of Internet. This artificial virtual space, derived from realistic world, has become a second space of human beings. Thus, we need to possess some abilities different from that in the past so as to achieve efficient production and enjoy high-quality life in the digital age, which is called digital capability. In order to meet the development and demands of digital society, University students should possess relatively stronger digital capability to constantly promote self digital capability for study and survival. Therefore, it is a realistic work to explore ways and countermeasures to promote University students' digital abilities.

\section{Digital Capability}

The Connotation of Digital Capability. At present, there hasn't been a unified concept for digital capability. Combined with the connotation of digital learning ability and digital survival ability [1-4], I believe digital capability of University students refers to their ability to obtain and employ resources from the environment, discover, explore and solve problems by using digital tools correctly so as to achieve high-efficient and high-quality life in the digital age. The digital capability includes digital learning ability and digital survival ability as well as some practical abilities like cooperation and survival in digital environment.

The Structure of Digital Capability. The digital capability is organically made up of study and survival in digital world as well as practical abilities of production, communication and life in Internet world. According to the five aspects of digital learning ability and the six aspects of digital survival ability[5-6], the structure of digital capability can be divided into six aspects, which are 
consciousness level, knowledge level, technology level, behavior level, management level and evaluation level. the six aspects of digital survival ability are described as follows (efer with: Table 1).

The Evaluation Index System of University Students' Digital Capabilities. At present, there hasn't been an evaluation system specially used for estimating University students' digital capabilities; however, American standards for higher education information literacy as well as digital learning capability have provided references and basis for the establishment of evaluation system. Through analysis on the six aspects of digital capabilities combined with University students' own psychological and cognitive features, 14 basic secondary evaluation indicators have been proposed as follows. (refer with table 1)

Table 1 Evaluation indicators of University students' digital capabilities

\begin{tabular}{|c|c|c|}
\hline $\begin{array}{l}\text { First-level } \\
\text { index }\end{array}$ & Second-level index & Description of the index \\
\hline \multirow{2}{*}{$\begin{array}{l}\text { Conscious } \\
\text { level } \\
\text { (A1) }\end{array}$} & Digital consciousness (B1) & $\begin{array}{l}\text { Support lifelong study and online study with active } \\
\text { participation in the study of digital tools. }\end{array}$ \\
\hline & Digital perception (B2) & have acute perceptive ability of digital learning tools \\
\hline \multirow{2}{*}{$\begin{array}{l}\text { Knowledge } \\
\text { level } \\
\text { (A2) }\end{array}$} & Cognition of digital tools (B3) & $\begin{array}{l}\text { Master basic knowledge and application of normal } \\
\text { digital tools }\end{array}$ \\
\hline & $\begin{array}{l}\text { Application of digital tools } \\
\text { (B4) }\end{array}$ & $\begin{array}{l}\text { Deal with practical problems timely with proper } \\
\text { digital tools after the discovery of problems }\end{array}$ \\
\hline \multirow{2}{*}{$\begin{array}{l}\text { Technology } \\
\text { level } \\
\text { (A3) }\end{array}$} & Tracking of digital tools (B5) & $\begin{array}{l}\text { Pay attention to the development situation of digital } \\
\text { tools }\end{array}$ \\
\hline & Digital communication (B6) & $\begin{array}{l}\text { Conduct effective communication and cooperative } \\
\text { study by Internet }\end{array}$ \\
\hline \multirow{3}{*}{$\begin{array}{l}\text { Behavior } \\
\text { level(A4) }\end{array}$} & $\begin{array}{l}\text { Acquisition of digital } \\
\text { resources (B7) }\end{array}$ & $\begin{array}{l}\text { Have the ability of quick selection of resources from } \\
\text { the complicated online resources with self } \\
\text { understanding }\end{array}$ \\
\hline & $\begin{array}{l}\text { Contribution of digital } \\
\text { resources (B8) }\end{array}$ & $\begin{array}{l}\text { Share significant online resources acquired by oneself } \\
\text { with others }\end{array}$ \\
\hline & Digital moral behaviors (B9) & $\begin{array}{l}\text { identify and resist online violence, eroticism and false } \\
\text { information temptation }\end{array}$ \\
\hline \multirow{3}{*}{$\begin{array}{l}\text { Management } \\
\text { level(A5) }\end{array}$} & Self management (B10) & have a good understanding of self-control ability \\
\hline & $\begin{array}{l}\text { Digital management of } \\
\text { resources (B11) }\end{array}$ & $\begin{array}{l}\text { have a rational reserve and efficient utility of network } \\
\text { learning resources }\end{array}$ \\
\hline & Management of time (B12) & $\begin{array}{l}\text { have a rational arrange of time for study and } \\
\text { entertainment to ensure the quality of study }\end{array}$ \\
\hline \multirow{2}{*}{$\begin{array}{l}\text { Evaluation } \\
\text { level(A6) }\end{array}$} & $\begin{array}{l}\text { Digital evaluation on } \\
\text { participation (B13) }\end{array}$ & $\begin{array}{l}\text { have a reasonable evaluation on self participation in } \\
\text { digitization }\end{array}$ \\
\hline & $\begin{array}{l}\text { Digital evaluation on } \\
\text { resources (B14) }\end{array}$ & $\begin{array}{l}\text { have a rational evaluation on the roles of online } \\
\text { resources and learning tools during the study }\end{array}$ \\
\hline
\end{tabular}

\section{Analysis on the Investigation Results of University Students' Digital Capabilities}

The purpose of this survey is to know about the situation of University students' digital capabilities. The questionnaire method is adopted in this survey, and the investigation subjects are students in Xiang Nan University. The time of survey is March 2015. There are totally 300 pieces of questionnaires are given out in this survey, during which there are 285 valid questionnaires. 117 pieces of them are filled out by boy students, accounting for $41.05 \%$; while 168 pieces are filled out 
by girl students, accounting for $58.95 \%$. Since girl students are more than boy students in this school, so the distribution is basically rational. In addition, the survey sample is relatively coordinated among different grades with rational structure, which is of strong representative and statistical significance.

The contents of this survey are based on the digital capability evaluation indicators, which analyzes University students' digital capabilities from consciousness level, knowledge level, technology level, behavior level, management level and evaluation level so as to define current level and existing problems. Thus, it can help to carry out training on University students' digital capabilities to promote their digital level.

\section{Analysis on the Conscious Level of Digital Capability(A1).}

Digital Consciousness(B1).The digital consciousness mainly analyzes University students' consciousness about lifelong study, digital study and employment of digital resources to solve problems. According to the survey, $36.49 \%$ students are identified with digital resources with frequent usage; while $42.11 \%$ students are identified with digital tools but with less usage. The rest $21.4 \%$ students are not satisfied with digital tools. $52.28 \%$ students actively use digital tools for lifelong study, which achieves much support. That is, most students identify the value of lifelong study in the digital age, but they have low interest in using them.

Digital Perception(B2).Digital perception mainly manifests on University students' cute perceptive capability of digital tools, which can show University students' consciousness of digital capability to some degree. The survey shows that $55.09 \%$ students can discover some tools helpful for their study, $22.81 \%$ students can always find some helpful tools, but there are still $20.7 \%$ student can seldom find useful tools. In digital age, whether University students can perceive digital tools or not determines if they can follow the social changes.

Analysis on the Knowledge Level of Digital Capabilities. With the development of information technology, the digital age has come into being, so we have to possess certain digital knowledge reserve to follow social development.

Knowledge about Digital Tools(B3). According to the survey, $62.46 \%$ students can proficiently master the employment of digital tools, and 30.18\% students can master the employment very well. Only a few students can basically master the usage with relatively poor level.

Employment of Digital Tools(B4). 28.42\% and 58.60\% students choose "always" and "often" respectively, while $10.88 \%$ students choose "seldom", which indicates that most students are familiar about the right usage of digital tools.

\section{Analysis on the Technology Level of Digital Capabilities.}

Tracking of Digital Technology(B5). According to the survey, 32.98\% students choose "always" for information searching, while $73.68 \%$ students choose "seldom" and "never" for information selection. That is to say, University students have a medium level of dealing with practical operation with relatively larger space for further development.

Digital Coordination(B6). The data shows that $24.71 \%$ or fewer students seldom or never conduct communication or coordination by Internet. Most of them only have group communication or coordination under teachers' assignment without initiative.

\section{Analysis on the Behavior Level of University Students' Digital Capabilities.}

Acquisition of Digital Resources(B7). In the digital age, information has become a key resource, so how to discover and acquire information quickly and accurately has become a necessary way to promote competitive advantage so as to achieve bigger profit to certain degree. About $27 \%$ students think it difficult to exchange knowledge, which needs further enhancement. 
Digital Resource Sharing(B8). Many learning resources are shared in the virtual world by people on the Internet, and the virtual learning resources can become more and more complete when more and more users participate in the sharing, which can also help to improve their capability. The data shows that only $18.95 \%$ users would like to share their discoveries with others actively, and $16.84 \%$ users never share any resources. Thus, we University students should learn to share information and resources with others.

Digital Moral Behaviors(B9). Nowadays more and more information resources have been accumulated on the Internet, within which there is some junk information, which can cause great damage for teenagers. Faced with junk information, most people choose to shut down the window, while there are still $28.42 \%$ students don't choose to shut down until they see the influence. As a member of digital society, we have the duty to keep network clean and healthy.

\section{Analysis on the Management Level of University Students' Digital Capabilities}

Through the survey, we find that nearly $72 \%$ students possess sound self-control ability, while there are still 28.07 students can't management themselves very well, which needs teachers' supervision to achieve high self-control ability.

The precondition of promoting digital capabilities is to possess large amount of data resources, but the possession and usage are not in direct proportion since $34.38 \%$ students haven't used resources very well. Therefore, University students should collect materials carefully and improve their judgment of high-quality resources with high utility rate of resources so as to create more values.

During University life, it is important management ability for University students to arrange study and entertainment time rationally. They can have both good rest and good study with rational arrangement. According to the survey, $8.07 \%$ students pay more attention to entertainment. Thus, some students still need to promote their management ability of time so as to better adapt to the fast development of society.

\section{Analysis on the Evaluation Level of University Students' Digital Capabilities.}

Digital Evaluation on the Participation(B13). By evaluating personnel and tools during the establishment of digital capabilities, Universitys' students' reflection on the function of resources including human resources and materials can be promoted to some extent. In contrast, we find that University students pay more attention to the role of personnel during the cultivation of digital capabilities. As a member of digital age, we should learn to use proper tools to fulfill ourselves to make preparations for future development.

Digital Evaluation on Resources(B14). Different students have different learning progress and effects due to different acceptability, study interest and learning methods. Thus, we should constantly make adjustment and evaluation on our learning progress and effect so as to solve problems timely.

According to the survey result, 36.49\% students make frequent reflections and evaluation on themselves, $24.21 \%$ students seldom reflect and evaluate on themselves, and even $10.18 \%$ students never reflect or evaluate. Therefore, we can see some students don't pay attention to the establishment of digital capabilities with little interest or initiative in promoting capabilities by using digital capabilities.

\section{Summary or the Survey}

According to the analysis above, we find that most University students have relatively digital consciousness with certain digital capability basis, but their digital capability is not very strong due to less initiative and low proficiency; and they also have poor learning environment with less study 
exchanges, coordination as well as deficient data sharing awareness and evaluation refection. Most University students have possessed basic digital capabilities and corresponding information literacy, but they still have some disadvantages. Thus, in order to promote students' digital capabilities, the key section is to promote students' initiative of using digital tools by enhancing the construction of digital infrastructure and improving resources so as to raise their learning interest and so on. By this way, they can follow the development of the society.

Strategies to Promote University Students' Digital Capabilities. There are two ways to promote University students' digital capabilities. One is to promote University students' own digital capabilities from consciousness, self management, reflection and practical capability; on the other hand, promotion of University students' digital capability relies on sound University atmosphere. Universitys can promote University students' digital capabilities from the construction of digital environment, digital capability training and digital resource construction.

\section{Measures for University Students to Promote Digital Capabilities.}

Build Digital Consciousness with Active Study. With the development of society, various fresh things have been emerging constantly. In digital age, students should set digital consciousness. By questionnaire data, we know that University students have little interest in the usage of digital tools and coordination of study. Thus, students should study excellent digital technology and knowledge actively by adjusting their own thoughts, and meanwhile they should learn to share resources actively so as to raise their interest and ability in the employment of digital tools.

Enhance Self Management. Since the Internet has huge information and various contents, many University students may get lost without effective self management. Under this circumstance, University students should have clear learning motivation to resist bad temptation with rational arrangement of time so as to promote their abilities.

Make Reflections and Evaluations. In the digital learning environment, University students should learn to reflect on themselves regularly so as to make adjustment timely, and thus they can master their learning process and test their learning effect.

Solve Problems Effectively by Combing with the Practice. Due to the development of information technology, digitization has infiltrated into various aspects of daily life. Therefore, University students should learn to solve practical problems based on practical situation by digital theories, methods and tools to promote their practical abilities.

\section{Countermeasures to Promote University Students' Digital Capabilities by Schools.}

Create Sound Environment for Digital Study and Application. The establishment of digital capability can be directly affected by the digital environment. According to the questionnaire, about $12 \%$ students think a sound digital learning environment is wanted. Therefore, Universitys and universities should create sound physical environment, perfect multi-media classrooms, guarantee campus wifi coverage, strengthen the construction of campus network and build online teaching platform by Internet.

Strengthen the Construction of Learning Infrastructure for Digital Capabilities. University students have abundant time to receive new concepts and skills, so Universitys and universities should strengthen the publication of digital capabilities so that students can have further understanding of it. The questionnaire shows that nearly $47.23 \%$ students haven't received related training on digital tools without certain skills or high learning motivation. Thus, Universitys should also open related courses and carry out corresponding competition activities to raise students' learning interest.

Learn to Optimize Resources. The cultivation of digital capabilities will be fruitless if students have no qualified learning resources. The questionnaire shows that $39.56 \%$ University students 
think the cultivation of digital capabilities is lack of abundant digital resources. Therefore, schools should enhance the construction of qualified digital resources with rational classification for students' quick inquiry. Besides, Universitys and universities can also share information and resources by network data sharing to promote the utility rate of resources.

\section{Acknowledgment}

This study is supported by social science program(NO: 13YBB205), Hunan province ordinary university teaching reform project in 2013 (Research and Practice on Investigative Teaching for Management and Information System based on network space), planned project of investigative study and innovative experiment on student in XiangNan University (Study on the promotion of University students' information literacy based on the study of network space), the scientific and research project of XiangNan University (study on the establishment of practical teaching system for communication and management major in local universities), project of teaching reform in XiangNan University (Application of investigative study in the teaching of the management information system), and the key discipline in Xiangnan University (XNU125KD031).

\section{References}

[1] Gong Huaping, Gong Yi. Strategies for the Establishment of Digital Study and Learning Society [J]. Study on library science,2011(9):41-65.

[2] Li Kedong. Digital Study (A) -Core of Information Technology and Course Integration [J].Chinese Study on E-Education,2001,(8):46-49.

[3] Huang Yunlong, Digital Study - The Third Mark of Human's Learning Development History [J].Growth and Employment,2010,(5):37.

[4] [American] written by Nick and translated by Hu Yong. Digital Survival[M]. Hai Kou:Press of Xiamen University, 1997.

[5] Zhang Lixia, Yuanli. Interpretation of the Connotation and Structure of Digital Survival Capability[J].Chinese E-Education,2012,(1):24-28.

[6] Ouyang Youquan. Network Communication and Social Culture.[M].Press of Beijing Higher Education,2005.

[7] Zhang Lixin. Two Worlds, Two Teaching Modes[J].Chinese E-Education,2009,(6):7-9. 